\title{
Bovine cardiac troponin I gene (TNNI3) as a candidate gene for bovine dilated cardiomyopathy
}

\author{
MARTA OWCZAREK-LIPSKA ${ }^{1}$, GAUDENZ DOLF ${ }^{1}$, KARINA E. GUZIEWICZ ${ }^{2}$, TOSSO LEEB ${ }^{1}$, \\ CLAUDE SCHELLING ${ }^{3}$, HORST POSTHAUS ${ }^{4}$ and MARTIN H. BRAUNSCHWEIG ${ }^{1}$
}

\begin{abstract}
${ }^{1}$ Institute of Genetics, Vetsuisse faculty, University of Berne, Berne, Switzerland, ${ }^{2}$ School of Veterinary Medicine, Ryan Veterinary Hospital, University of Pennsylvania, Philadelphia, USA, ${ }^{3}$ Veterinary Genetics, Vetsuisse faculty, University of Zurich, Zurich, Switzerland, ${ }^{4}$ Institute of Animal Pathology, Vetsuisse faculty, University of Berne, Berne, Switzerland
\end{abstract}

\section{Abstract}

The cardiac troponin complex, which is an important component of the contractile apparatus, is composed of the three subunits troponin I (Tnl), troponin C (TnC) and troponin T (TnT). Troponin I is the inhibitory subunit and consists of three isoforms encoded by TNNI1, TNNI2 and TNNI3 genes, respectively. Due to the different types of cardiomyopathies caused by mutations in the TNNI3 gene and its fluorescence in situ hybridization (FISH) mapping on bovine chromosome 18q26, which was shown to be linked to the recessively inherited bovine dilated cardiomyopathy (BDCMP), bovine TNNI3 was considered as candidate gene for BDCMP.

Real-time polymerase chain reaction (PCR) TNNI3 expression analysis resulted in a significant difference between BDCMP affected and unaffected animals when normalized to $A C T B$ gene expression, but there was no significant difference in expression when normalized to GAPDH. Northen blotting experiment was in agreement with the expression analysis and did not reveal a significant difference between the group of BDCMP affected and unaffected animals. Sequencing of the bovine $T N N / 3$ gene revealed a single nucleotide polymorphism in intron 6 (c.378+315G $>A)$, but this single nucleotide polymorphism (SNP)was present regardless of the BDCMP status. In summary our data provide evidence to exclude the bovine TNNI3 gene as a candidate for BDCMP.

Keywords: troponin complex, cardiac troponin I gene (TNNI3), bovine dilated cardiomyopathy (BDCMP), Swiss Fleckvieh, cattle

\section{Zusammenfassung}

\section{Bovines Cardiac Troponin I Gen (TNNI3) als Kandidatengen für die bovine dilatative Kardiomyopathie}

Der Cardiac Troponin Komplex, welcher eine wichtige Komponente des kontraktilen Apparates ist, setzt sich aus den drei Untereinheiten Troponin I (Tnl), Toponin C (TnC) und Troponin T (TnT) zusammen. Troponin I ist die inhibitierende Untereinheit und besteht aus drei Isoformen, die durch die Gene TNNI1, TNNI2 und TNNI3 kodiert sind. Verschiedene Formen der Kardiomyopathie beim Menschen werden durch Mutationen 
im TNNI3 Gen verursacht. Das bovine TNNI3 Gen wurde auf dem Chromosom 18q26, welches mit der rezessiv vererbten bovinen dilatativen Kardiomyopathie (BDCMP) gekoppelt ist, durch Fluoreszenz-in-situ-Hybridisierung (FISH) physikalisch kartiert und als Kandidatengen für BDCMP untersucht.

Die Echtzeit-Polymerase-Kettenreaktion (Real-Time-PCR) TNNI3 Expressionsanalyse ergab einen signifikanten Unterschied zwischen BDCMP kranken und gesunden Tieren bei einer Normalisierung mit der ACTB Genexpression, aber es zeigte sich kein signifikanter Unterschied bei einer Normalisierung mit der GAPDH Genexpression. Northern Blotting Experimente bestätigten die Resultate der Expressionsanalyse und zeigten ebenfalls keine signifikanten Unterschiede in der TNNI3 Genexpression zwischen BDCMP kranken und gesunden Tieren. Die Sequenzierung des bovinen TNNI3 Gens zeigte eine Punktmutation im Intron 6 (c.378+315G>A), diese kam jedoch unabhängig vom BDCMP Status bei den untersuchten Tieren vor. Zusammenfassend erlauben unsere Untersuchungen, das das bovine TNNI3 Gen als Kandidat für die BDCMP ausgeschlossen werden kann.

Schlüsselwörter: Troponinkomplex, Cardiac Troponin I Gen (TNNI3), bovine dilatative Kardiomyopathie (BDCMP), Schweizerisches Fleckvieh, Rind

\section{Introduction}

The troponin complex is composed of the three subunits: troponin I (Tnl), troponin C (TnC) and troponin $\mathrm{T}(\mathrm{TnT})$, which interact during muscle contraction and relaxation with actin via tropomyosin (GOMES et al. 2002). Tnl consists of three isoforms. Two of them, coded by the genes TNNI1 and TNNI2, are present in slow-twitch and in fast-twitch skeletal muscles, and the third form coded by the TNNI3 gene is present in heart muscle (CUMMINS and PERRY 1978, TISO et al. 1997). Human cardiac Tnl protein has an animo-terminal extension with the RRRSS sequence. This sequence is also present in rat and cattle counterparts (VALLINS et al. 1990, MITTMANN et al. 1992). Phosphorylation on both serines (S) results in a reduction of the interaction between troponin I and troponin $C$ and this leads to an increase in heart contractility (LIAO et al. 1992). It has been shown that the majority of mutations found in the TNNI3 gene are responsible for hypertrophic cardiomyopathy (KIMURA et al. 1997, MOGENSEN et al. 2004). However, MURPHY et al. (2004) reported a rare TNNI3 mutation causing idiopathic dilated cardiomyopathy in human.

Bovine dilated cardiomyopathy (BDCMP) is a severe and terminal heart disease. BDCMP affects animals belonging to the Red Holstein breed and to Red Holstein $\times$ Simmental crosses (Swiss Fleckvieh) (GRABER and MARTIG 1993). DOLF et al. (1998) confirmed an autosomal recessive inheritance of a major gene for BDCMP by segregation analysis using an experimental pedigree. In a recent study we showed by linkage analysis that the BDCMP locus maps to bovine chromosome 18 (BTA18) (GUZIEWICZ 2007).

Here we present conclusive evidence that the bovine $T N N / 3$ gene can be excluded as a candidate gene for BDCMP. 


\section{Material and methods}

\section{Cloning and physical mapping of the bovine TNNI3 gene}

The following primers to amplify exon 7 of $T N N / 3$ were used to screen a bovine genomic DNA BAC library comprising 105984 clones (EGGEN et al. 2001): forward primer TNNI3ex7f 5'-TGA CCTTCG AGG CAA GTTTA-3' and reverse primer TNNI3ex7r 5'-TCC TCC TTC TTC ACC TGC TT-3'. The primers were deduced from the orthologues DNA sequence of human TNNI3 with the acc. no. X90780.

A single colony from BAC clone 388A05, containing the $T N N / 3$ gene, was inoculated into the $5 \mathrm{ml} \mathrm{LB}$ medium with $12.5 \mu \mathrm{l} / \mathrm{ml}$ chloramphenicol and incubated at $37^{\circ} \mathrm{C}$ with shaking (300 rpm) during 6-8 h. Afterwards, the culture was diluted (1/1000) into selective LB medium and incubated at $37^{\circ} \mathrm{C}$ with shaking over $12-16 \mathrm{~h}$. The BAC DNA (7-15 $\left.\mu \mathrm{g}\right)$ was extracted according to the manufacture's recommendations using a NucleoBond PC-Kit (Macherey-Nagel AG, Oensingen, Switzerland).

The DNA from the BAC clone 388A05 was digested with Sau3Al restriction enzyme. The obtained fragments, were labeled with biotin-16-dUTP (Roche Diagnostics, Rotkreuz, Switzerland) by the random priming DNA labeling method with Prime-It Fluor Fluorescence Labeling Kit according to the manufacturer's protocol (Stratagene, Amsterdam, The Netherlands). Bovine mitotic metaphase chromosomes from fibroblast culture were QFQ stained and hybridized with the labeled BAC probe (SOLINAS-TOLDO et al. 1995). FISH results were analyzed with a fluorescence light microscope under the $63 \mathrm{x}$ oil immersion objective and photographed using Quantix Camera (Photometrics, Tucson, USA).

\section{Sequencing of the bovine TNNI3 gene}

The DNA from three BAC clones (388A05, 477A02 and 428H02) containing at least part of the TNN/3 gene were pooled, partially digested with Sau3AI and cloned into pUC19 vector (Roche Diagnostics, Rotkreuz, Switzerland). White positive colonies were picked and transferred in 96-well deep well plates (Milian Instruments SA, Geneva, Switzerland) with each well containing $1 \mathrm{ml} \mathrm{LB}$ with $10 \%$ glycerol and ampiciline $(100 \mu \mathrm{g} / \mathrm{ml})$. After incubating for $20 \mathrm{~h}$ at $37^{\circ} \mathrm{C}$ with vigorous shaking (300 rpm) about $200 \mu \mathrm{l}$ suspension of each clone were transferred into 96 -well microtiter plate and stored at $-80^{\circ} \mathrm{C}$ for further analysis. This bovine plasmid sub-library from the three BACs was first screened by using human $T N N / 3$ gene exon 7 specific primers, mentioned above, and following DNA sequencing with the corresponding bovine specific primers to identify clones harbouring part of the bovine TNNI3 gene. Plasmid DNA of positive clones was sequenced using the Sequenase Fluorescent Labelled Primer Cycle Sequencing Kit (Amersham Biosciences, Dübendorf, Switzerland) according to the manufacturer's recommendations. The sequencing reactions were run on $4.3 \%$ denaturing polyacrylamide gels on an automated DNA Sequencer LI-COR 4200 (LI-COR, Bad Homburg, Germany) and analysed with a software packages eSeq and AlignIR (LI-COR). 
Association analysis of SNP in intron 6 of the bovine TNNI3 gene

DNA from 170 blood samples and paraffin embedded tissues were extracted according to standard protocols. Samples from 136 BDCMP affected animals of Swiss Fleckvieh and 34 unaffected animals consisting of 16 Swiss Fleckvieh, 10 Holstein-Friesian and 8 Simmental were used. These animals were genotyped for the SNP in intron 6 of the bovine TNNI3 gene (c.378+315G $>A)$.

$P C R$ products surrounding the SNP were obtained with primers TNNI3intron6_f 5'-GGG ATT CTC CAG ACA AGA ACA C-3' and TNNI3intron6_r 5'-CCA CAC TTG AGC TGA CTT ACC $A-3^{\prime}$ and sequenced form the both sides on an $A B I 3730$ capillary sequencer (Applied Biosystems, Rotkreuz, Switzerland). Sequencing results were analyzed using the Sequencher 4.6 software (Gene Codes Corporation, Ann Arbor, USA).

\section{RNA extraction and first CDNA strand synthesis}

Total RNA from heart tissues of 4 BDCMP affected and 9 BDCMP unaffected animals was extracted using TRIZOL Reagent (Invitrogen, Basel, Switzerland) and reverse transcribed using the First-Strand cDNA Synthesis Kit (GE Healthcare, Basel, Switzerland).

\section{5'-RACE experiment}

The $5^{\prime}$ rapid amplification of CDNA ends of the bovine TNNI3 gene (5'-RACE) was performed using the FirstChoice RLM-RACE Kit according to the manufacturer's protocol (Ambion, Rotkreuz, Switzerland).

\section{Expression analysis of the bovine TNNI3 gene}

PCR products from the coding regions of bovine GAPDH (glyceraldehydes-3-phosphate dehydrogenase), ACTB (actin beta) and TNNI3 (cardiac troponin I) genes were cloned and transformed into E. coli cells (TOPO TA Cloning Kit, Invitrogen, Basel, Switzerland). The plasmids were used to create RNA probes for the Northern analysis. Primers and TaqMan probes for these genes were designed using Applied Biosystems' primer express software (Applied Biosystems, Rotkreuz, Switzerland) and based on the sequence of the cloned PCR products. Sequences of primers and probes are listed in Table 1.

Table 1

Primers and TaqMan probes used for the real time PCR experiment

Primer und TaqMan Proben, die für das Real-Time-PCR Experiment verwendet wurden

\begin{tabular}{ll}
\hline Gen & Oligonucleotide $\left(5^{\prime}\right.$ to $\left.3^{\prime}\right)$ \\
\hline & F: CGG ACA GGA TGC AGA AAG AGA \\
ACTB & ProbG CGC GAT GAT CCT GAT \\
& F: CCC ACT CCC AAC GTG TCT GT \\
GAPDH & R: CCA CCT TCT TGA TCT CAT CAT ACT TG \\
& Probe: CTG ACC TGC CGC CTG GAG AAA CCT \\
& F: CGC ACG CCA CGC AAA AGT \\
TNNI3 & R: CTG CAG CAT CAG GGT CTT CA \\
& Probe: AAG ATC TCC GCC TCA AGG AAA CTG CAG
\end{tabular}


The real time PCR experiment was performed according to the guidelines form Applied Biosystems, on a 7300 Real-Time PCR System. The real time PCR data were analyzed by the relative quantification $\Delta \Delta C_{T}$ method (SCHMITTGEN and LIVAK 2008). The expression level is given as fold difference compared to a calibrator sample.

\section{Northern blot analysis and detection of antisense transcript of the TNNI3 gene}

Northern analyses were performed according to standard protocols. RNA probes were synthesized using the MAXIscript Kit (Ambion, Rotkreuz, Switzerland) with a DY-681-aaUTP conjugate (DYOMICS, Jena, Germany). Hybridization was carried out according to the protocol accompanying the ULTRAhyb hybridization buffer (Ambion, Rotkreuz, Switzerland). The Northern blot was analyzed on an Odyssey Infrared Imaging System (LI-COR).

\section{Bioinformatics analyses}

The amino-acid sequences from the cardiac troponin I protein (cardiac Tnl) encoded by TNNI3 gene were compared between bovine (UniProt acc. no. P08057), equine, human, mouse, chicken, African clawed frog and zebrafish (GenBank acc. no. NP_001075373, NP_000354, NP_033432, NP_998735, NP_001088122, NP_001008613, respectively) using the ClustalW2 multiple alignment (http://www.ebi.ac.uk/Tools/clustalw2/index.html). To estimate the percentage of identity between the amino-acid sequence of the bovine cardiac $\mathrm{Tnl}$ and amio-acids sequences from the cardiac $\mathrm{Tnl}$ protein from the above maintained species BLAST analysis (http://blast.ncbi.nlm.nih.gov/bl2seq/wblast2.cgi) was performed.

\section{Results and discussion}

Physical mapping and sequencing of the bovine TNNI3 gene

Three bovine clones (388A05, 477A02 and 428H02) containing the TNN13 gene were isolated from the bovine BAC library for mapping and sequencing purposes. The FISH experiment performed with BAC clone $388 \mathrm{~A} 05$ as a probe on bovine metaphase chromosomes revealed the position of the bovine counterpart gene on BTA 18q26 (Figure 1). BERMINGHAM et al. (1995) mapped the human TNNI3 gene to HSA 19q13.3q13.4. This chromosomal position is in accordance with the well established synteny between human chromosome 19 and bovine chromosome 18 (GOLDAMMER et al. 2004, MÖMKE et al. 2005). Both, the human TNNI3 and the bovine TNNI3 gene are composed of eight exons (Figure 2). The comparison between the human (GenBank acc. no. NM_000363) and bovine (GenBank acc. no. AJ842179) coding sequences revealed an identity of $88.5 \%$. Similar to the human TNNI3 gene an ATG start codon and a TGA stop codon were identified in the respective exon 1 and exon 8 of the bovine ortholog (Figure 2). The transcription start site of the bovine TNNI3 gene was confirmed by a $5^{\prime}$-RACE experiment and is in agreement with the reported sequence of bovine fetal liver mRNA (GenBank acc. no. BC102731). The transcribed TNNI3 mRNA encodes a 212 amino-acid protein. The bovine cardiac Tnl protein sequence shares $92 \%$ identity to human, $93 \%$ and $91 \%$ identity to, equine and mouse, respectively. These three species are almost completely identical in 
the conserved domains. Additionally, more divergent species, like the chicken, the African clawed frog and the zebrafish, show a amino-acid identity of $65 \%, 73 \%$ and $63 \%$, respectively (Figure 3).

Figure 1

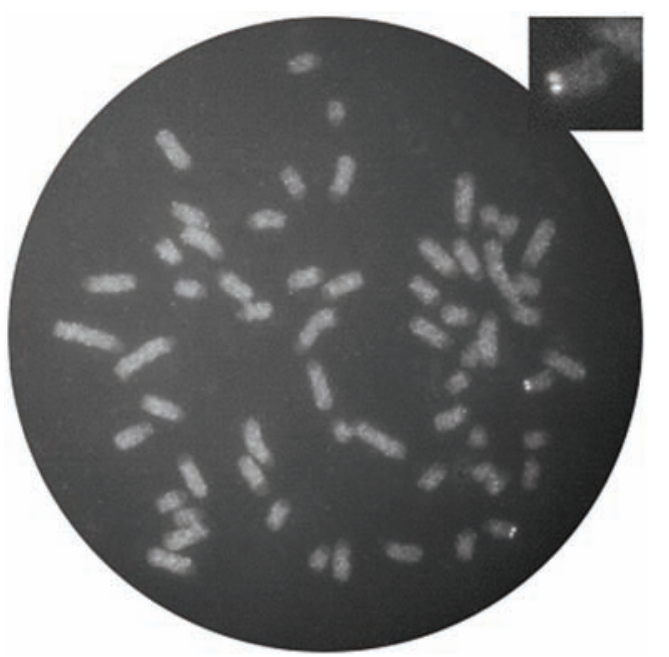

FISH mapping of the bovine TNNI3 gene. The biotin-16-dUTP labeled BAC clone 388A05 hybridized to QFQbanded methaphase chromosomes and identified the position of the bovine TNNI3 gene on BTA18q26. Chromosomes were analysied using the $63 x$ oil immersion objective.

FISH Kartierung des bovinen TNNI3Gens. Der biotin-16-dUTP markierte BAC Klon 388A05 hybridisiert an die QFQ-gebänderten Metaphasenchromosmen und identifiziert die Position des bovinen TNNI3 Gens auf dem BTA18q26. Die Chromosomen wurden mit einem 63x Ölimmersionsobjektiv analysiert.

\section{TNNI3 gene}

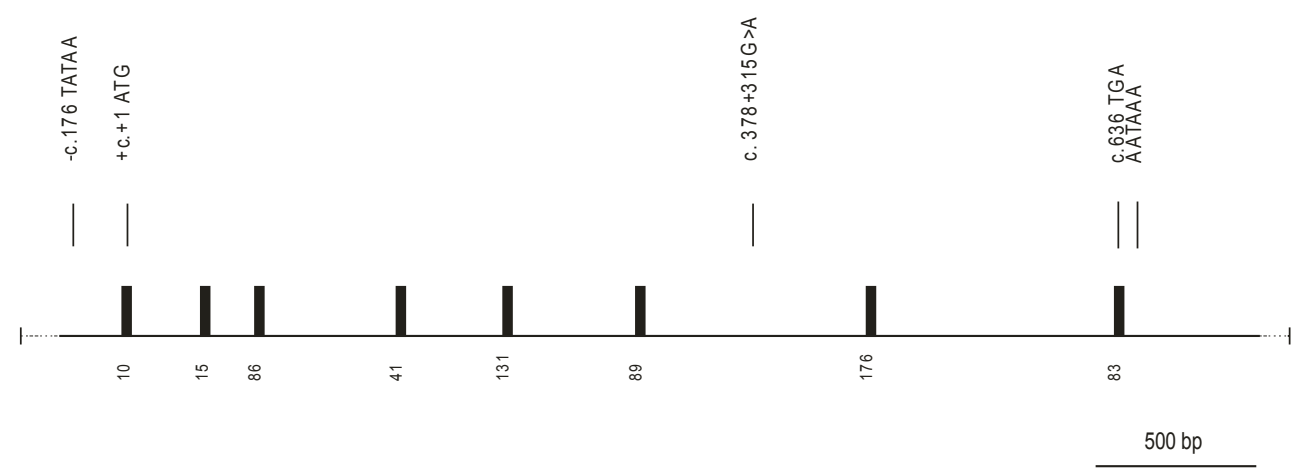

Figure 2

Bovine TNNI3 gene structure including the position of SNP in intron 6. ATG start codon, TGA stop codon, TATAA sequence and polyadenylation signal are indicated. The exons are shown in black boxes and their sizes are given below.

TNNI3 Gen Struktur mit der Position der Punktmutation im Intron 6. ATG Startkodon, TGA Stopkodon, TATAA Sequenz und Polyadenylationssignal sind angegeben. Die Exons sind in schwarzen Boxen mit darunter stehenden Größenangabe aufgezeigt. 
Bos taurs

Equus caballus

Mus musculus

Homo sapiens

Gallus gallus

Xenopus laevis

Danio rerio

Bos taurs

Equus caballus

Mus musculus

Homo sapiens

Gallus gallus

Xenopus laevis

Danio rerio

Bos taurs

Equus caballus

Mus musculus

Homo sapiens

Gallus gallus

Xenopus laevis

Danio rerio

Bos taurs

Equus caballus

Mus musculus

Homo sapiens

Gallus gallus

Xenopus laevis

Danio rerio

Bos taurs

Equus caballus

Mus musculus

Homo sapiens

Gallus gallus

Xenopus laevis

Danio rerio

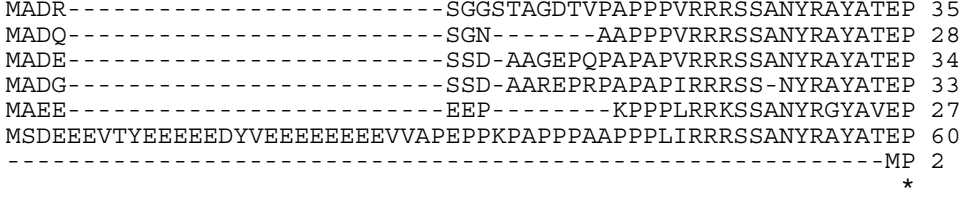

HAKKKSKISASRKLQLKTLMLQIAKQELEREAEERRGEKGRALSTRCQPLELAGLGFAEL 95 HAKKKSKISASRKLQLKTLMLQIAKQELEREAVERRGEKGRALSTRCQPLELAGLGFEEL 88 HAKKKSKISASRKLOLKTLMLOIAKOEMEREAEERRGEKGRVLRTRCOPLELDGLGFEEL 94 HAKKKSKISASRKLQLKTLLLQIAKQELEREAEERRGEKGRALSTRCQPLELAGLGFAEL 93 HAKRQSKISASRKLQLKTLLLQRAKRELEREEQERAGEKQRHLGELCPP PELEGLGVAQL 87 QVKIKPKISASRKLQLKSLMLQIAKAEMEHEEEERALEKERYLAEQCQPLQLSGLSLSEL 120 EQEKKSKISASRKLMLKSLMVAKAKEELEQELADKEDEKEKYLSEKAPQLQTSGMSFAEL 62

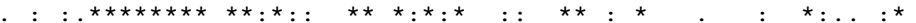

QDLCRQLHARVDKVDEERYDVEAKVTKNITEIADLNQKIFDLRGKFKRPTLRRVRISADA 155 ODLCROLHARVDKVDEERYDVEAKVTKNITEIADLNOKIFDLRGKFKRPTLRRVRISADA 148 QDLCRQLHARVDKVDEERYDVEAKVTKNITEIADLTQKIYDLRGKFKRPTLRRVRISADA 154 QDLCRQLHARVDKVDEERYDIEAKVTKNITEIADLTQKIFDLRGKFKRPTLRRVRISADA 153 QELCRELHAR IGRVDEERYDMGTRVSKNMAEMEELRRRVAG - -GRFVRPALRRVRLSADA 145 QDLCRELHARIDVVDEERYDMEAEVNKNITEIEDLNLKIFDLRGKFKKPNLRRVRLSADA 180 QELCRELHAKIDVVDEERYDIEAKVLHNTREIKDLNIKVLDLRGKFKRPTLRRVRVSADA 122

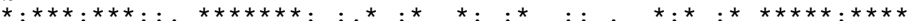

MMOALLGARAKETLDLRAHLKOVK - - KEDTEKE-NREVGDWRKNIDALSGMEGRKKKFE 211 MMQALLGTRAKETLDLRAHLKQVK - - KEDTEKE-NREVGDWRKNIDALSGMEGRKKKFE 204 MMQALLGTRAKESLDLRAHLKQVK - - KEDIEKE-NREVGDWRKNIDALSGMEGRKKKFE 210 MMOALLGARAKESLDLRAHLKOVK - - KEDTEKE-NREVGDWRKNIDALSGMEGRKKKFE 209 MMAALLGSKHRVGTDLRAGLRQVR - - KDDAEKE-SREVGDWRKNVDALSGMEGRKKKFE 201 MMRALLGTKHKVSMDLRASLKQVKQTKKEDVDKD-IREVGDWRKNVDALSGMEGRKKKFE 239 ILRSLLGSKHKVSMDLRANLKSVK - - KEDTEKEKTVEVSDWRKNVEAMSGMEGRKKMFD 179

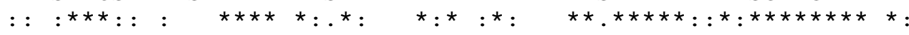

G-- - - 212

G-- - - 205

G-.-.- 211

S----- 210

APGGGQG 208

STGAVAV 246

$\mathrm{AAQ}---182$

Figure 3

Multiple alignment of the bovine cardiac Tnl protein (coded by TNNI3 gene) with the orthologous sequence of horse, mouse, human, chicken, African clawed frog and zebrafish. The amino-acid seqences from six different species were derived from GenBank. Residues, depending on to the similarity between the cardiac Tnl protein in diverse species, are presented by asterisks (identical) and colons or dots (very similar or similar). Conserved domains of the cardiac Tnl protein are indicated in bold.

Vergleich der bovinen Cardiac TnI Proteinsequenz (kodiert durch das TNNI3 Gen) mit den orthologen Sequenzen des Pferdes, der Maus, des Menschen, des Huhns, des Afrikanischen Krallenfrosches und des Zebrafisches. Die Sequenzen der sechs verschieden Spezies wurden der GenBank entnommen. Die Aminosäuren sind entsprechend der Ähnlichkeit zwischen dem Cardiac Tnl Protein der verschiedenen Spezien mit einem Stern (identisch), mit einem Doppelpunkt (sehr ähnlich) oder einem Punkt (ähnlich) markiert. Konservierte Domänen des Cardiac Tnl Proteins sind fett gedruckt.

\section{Analysis of the transition $G>A$ in intron 6 of the bovine TNNI3 gene}

Sequencing of the bovine TNNI3 gene in six affected and in six unaffected individuals revealed only a SNP in intron 6 (c.378+315G>A) (GUZIEWICZ 2004). In order to verify the association between the c.378+315G>A transition and BDCMP we genotyped 136 BDCMP affected and 34 unaffected animals of unknown ancestry. Within the group of BDCMP affected animals 70 (51.5\%) were homozygous AA, 9 (6.6\%) were homozygous GG and 57 (41.9\%) were heterozygous AG. The corresponding genotype frequencies for the group of unaffected animals, 4 (11.8\%) were homozygous AA, 10 (29.4\%) were homozygous GG and 20 (58.8\%) were heterozygous AG were observed. The allele frequencies between 
the two groups were significantly different (chi-square test, $P>0.001$ ) indicating that the c.378+315A allele is closely associated with BDCMP. In this context it is worth to mention that the majority of animals (152) from the Swiss Fleckvieh breed were genotyped. Nevertheless, since all three genotypes were present in the group of affected animals the c.378+315G $>$ A transition cannot be the causative mutation for BDCMP.

\section{Expression analysis, the Northern blotting and \\ detection of antisense transcript of the TNNI3 gene}

We then further quantified the $T N N / 3$ gene expression in heart tissues of the right ventricle. In the real time PCR experiment we used ACTB and GAPDH genes for data normalization. Amplification efficiencies of $99.8 \%$ for $A C T B, 98.4 \%$ for GAPDH, and $99.9 \%$ for TNNI3 genes were calculated. Expression of the TNNI3 gene was analyzed in heart tissue from four affected and eight unaffected Swiss Fleckvieh animals and compared to a calibrator sample from a healthy adult individual. No significant difference in the TNNI3 gene expression was found between affected and unaffected animals when it was normalized to the GAPDH gene expression (Wilcoxon two-sample test, two sided, $P=0.50$ ). In contrast, the expression of the TNNI3 gene differed in the two groups when it was normalized to the $A C T B$ expression (Wilcoxon two-sample test, two sided, $P=0.02$ ) (Figure 4).

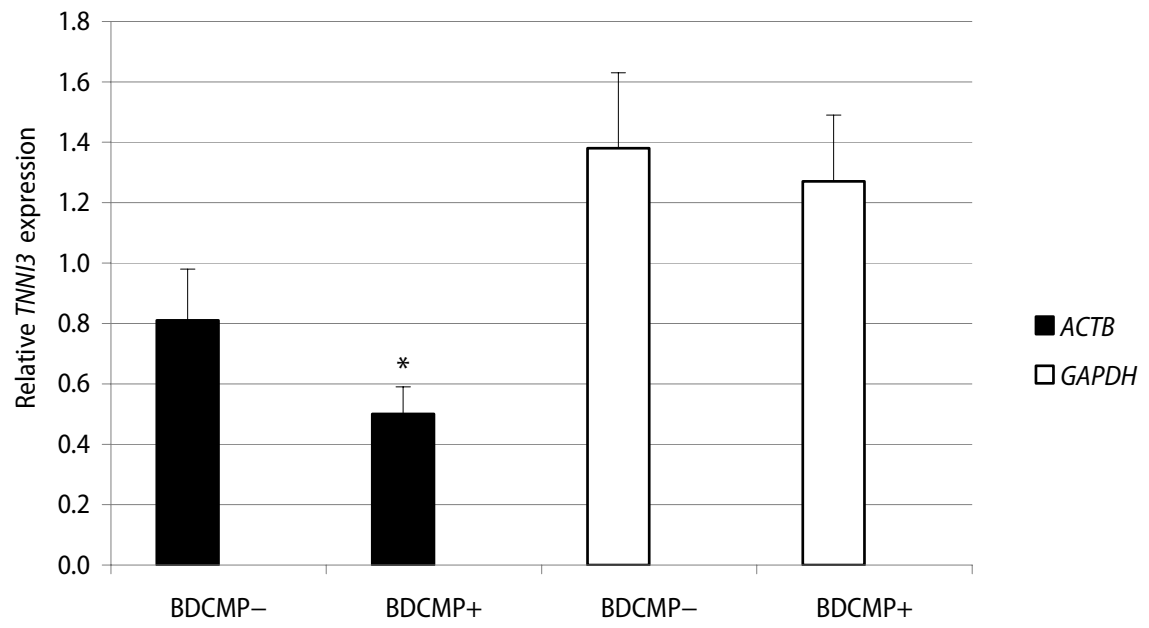

BDCMP unaffected (-) and affected (+) animals

Figure 4

Relative quantification of real-time PCR results of TNNI3 gene expression for unaffected (-) and BDCMP affected ( + ) animals. TNNI3 gene expression normailized to ACTB gene expression was significantly different between the two groups $(P=0.02)$ whereas no significant difference between the groups was found when normalized to GAPDH gene expression $(P=0.50)$.

Relative Quantifizierung der Real-Time-PCR Resultate der TNNI3 Genexpression für gesunde (-) und BDCMP erkrankte (+) Tiere. Die TNNI3 Genexpression war zwischen den beiden Gruppen signifikant verschieden, wenn zur ACTB Genexpression normalisiert wurde $(P=0.02)$. Dagegen wurde bei einer Normalisierung mit der GAPDH Genexpression $(P=0.50)$ kein signifikanter Unterschied zwischen den beiden Gruppen gefunden.

According to the achieved results we assume that the discrepancies in ACTB and GAPDH expression might be caused by changes in the composition of cells in BDCMP affected 
and unaffected heart tissues. During the disease development an increased amount of collagen fibers and a transmural myocardiofibrosis are observed (TONTIS et al. 1990). Differences in the abundance of $A C T B$ and GAPDH in fibroblasts and cardiomyocytes might be a reason of this inconsistency. However, the small sample number should also be considered.

In addition to the real time PCR experiment we performed a Nothern analysis. The mean expression ratio between TNNI3 and GAPDH genes in heart tissues of three affected and three unaffected animals were 1.6 and 2.1, respectively. However, it was found that the difference is not significant (Wilcoxon two-sample test, two sided, $P=0.1$ ) which is in agreement with the real time PCR experiment. The TNNI3 transcripts in affected and unaffected animals did not show any distinctive features as judged by the Northern blot (Figure 5). Furthermore we could not detect any TNNI3 gene antisense transcript as found in human and rat heart (BARTSCH et al. 2004). This indicates that there are no TNNI3 antisense transcripts present in bovine heart tissues or it is much less abundant then in human and rat heart.

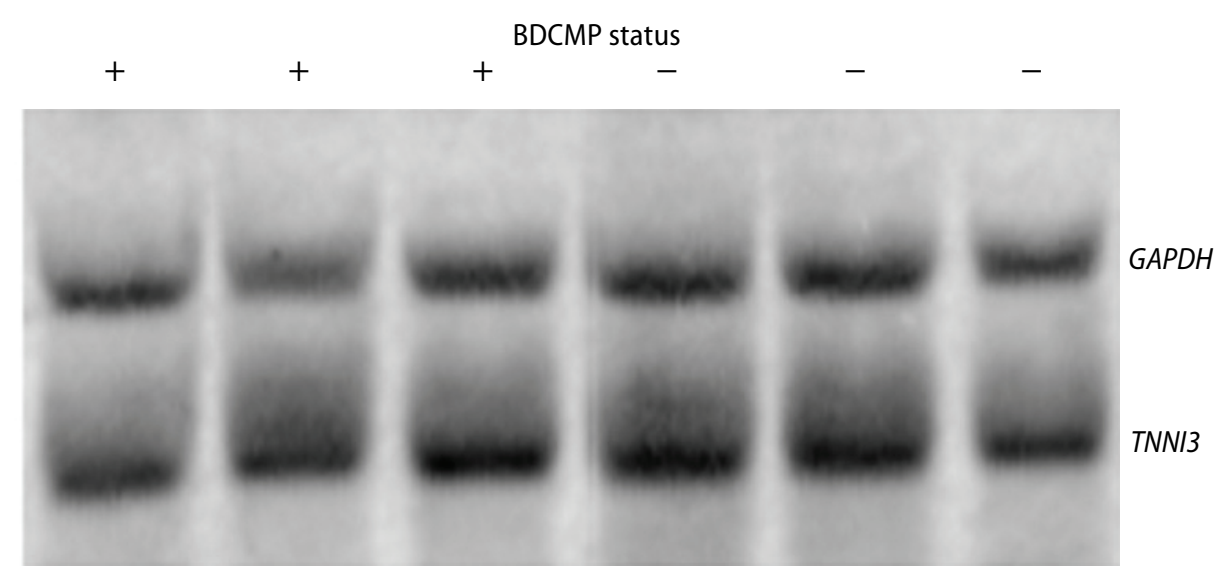

Figure 5

Northern blot analysis of the TNNI3 gene expression in three BDCMP unaffected $(-)$ and three BDCMP $(+)$ affected animals. TNNI3 gene expression was normalized to GAPDH gene expression.

Northern Blot Analyse der TNNI3 Genexpression in drei gesunden (-) und drei BDCMP erkrankte (+) Tiere. Die TNNI3 Genexpression wurde zur GAPDH Genexpression normalisiert.

In conclusion, the bovine TNNI3 gene, due to its chromosomal position and an essential function in contractile apparatus, was strongly suggested to be a plausible candidate gene for BDCMP. The recently fine mapping of BDCMP locus within a $6.7 \mathrm{Mb}$ interval, between microsatellite markers MSBDCMP06 and BMS2785 (GUZIEWICZ et al. 2007) excludes $T N N / 3$ gene as positional candidate gene. However, the TNNI3 gene could not be conclusively excluded as in the study's BDCMP pedigree a high LOD score of 3.37 was obtained at that locus. Therefore in the present study we described and thoroughly investigated the bovine $T N N / 3$ gene. A single intronic polymorphism in TNNI3 gene was found, but not in perfect disequilibrium with BDCMP mutation. Thus, we could exclude this mutation as being causative. Furthermore, the position of TNNI3 on the current 
bovine genome assembly (build 4.0) is more distal from the $6.7 \mathrm{Mb}$ interval than it was on the previous version of the bovine genome sequence (Btau 3.1) supporting the exclusion of this candidate gene. Additionally, the examination of the TNNI3 expression strongly supports that mutations in the bovine TNNI3 gene do not cause BDCMP.

\section{Acknowledgements}

The authors would like to thank Cord Drögemüller for advices and suggestions on the manuscript. This research was supported by the Swiss National Foundation (Project 3100AG-108230).

\section{References}

Bartsch H, Voigstberger S, Baumann G, Morano I, Luther HP (2004) Detection of a novel sense-antisense RNA-hybrid structure by RACE experiments on endogenous troponin I antisense RNA. RNA 10, 1215-24

Bermingham N, Hernandez D, Balfour A, Gilmour F, Martin JE, Fisher EM (1995) Mapping TNNC1 the gene that encodes cardiac troponin I in the human and the mouse. Genomics 30, 620-2

Cummins P, Perry SV (1978) Troponin I form human skeletal and cardiac muscles. Biochem J 171, 251-9

Dolf G, Stricker C, Tontis A, Martig J, Gaillard C (1998) Evidence for autosomal recessive inheritance of a major gene for bovine dilated cardiomyopathy. J Anim Sci 76, 1824-9

Eggen A, Gautier M, Billaut A, Petit E, Hayes H, Laurent P, Urban C, Pfister-Genskow M, Eilertsen K, Bishop MD (2001) Construction and characterization of a bovine BAC library with four genome-equivalent coverage. Genet Sel Evol 33, 543-8

Goldammer T, Kata SR, Brunner RM, Dorroch U, Sanftleben H, Schwerin M, Womack JE (2002) A comparative radiation hybrid map of bovine chromosome 18 and homologous chromosomes in human and mice. Proc Natl Acad Sci USA 99, 2106-11

Gomes AV, Potter JD, Szczesna-Cordary D (2002) The role of troponin in muscle contraction. IUBMB Life 54, 323-33

Graber HU, Martig J (1993) Diagnosis of bovine cardiomyopathy by electrolyte and protein analysis Zentralbl Vetmed A 40, 690-6

Guziewicz KE (2004) Bovine dilated cardiomyopathy evidence for a major gene on BTA18. PhD thesis Diss ETH Zurich No 15817

Guziewicz KE, Owczarek-Lipska M, Küffer J, Schelling C, Tontis A, Denis C, Eggen A, Leeb T, Dolf G, Braunschweig MH (2007) The locus for bovine cardiomyopathy maps to chromosome 18. Anim Genet 38, 265-9

Kimura A, Harada H, Park JE, Nishi H, Satoh M, Takahashi M, Hiroi S, Sasaoka T, Ohbuchi N, Nakamura T, Koyanagi T, Hwang TH, Choo JA, Chung KS, Hasegawa A, Nagai R, Okazaki O, Nakamura H, Matsuzaki M, Sakamoto T, Toshima H, Koga Y, Imaizumi T, Sasazuki T (1997) Mutations in the cardiac troponin I gene associated with hypertrophic cardiomyopathy. Nat Genet 16, 379-82

Liao R, Wang CH, Cheungs HC (1992) Time-resolved tryptophan emission study of cardiac troponin I. Biophys J 63, 986-95

Mittmann K, Jaquet K, Heilmeyer LM Jr (1992) Ordered phosphorylation of a duplicated minimal recognition motif for CAMP-dependent protein kinase present in cardiac troponin I. FEBS Lett 303, 133-7

Mogensen J, Murphy RT, Kubo T, Bahl A, Moon JC, Klausen C, Elliott PM, Mckenna WJ (2004) Frequency and clinical expression of cardia c troponin I mutation in 748 consecutive families with hypertrophic cardiomyopathy. J Am Coll Cardiol 44, 2315-25

Mömke S, Kuiper H, Spötter A, Drögemüller C, Distl O (2005) A refined radiation hybrid map of the telomeric region of bovine chromosome 18q25-q26 compared with human chromosome 19q13. Anim Genet 36, 141-5

Murphy RT, Mogensen J, Shaw A, Kubo T, Hughes S, Mckenna WJ (2004) Novel mutation in cardiac troponin I in recessive idiopathic dilated cardiomyopathy. Lancet 363, 371-2

Schmittgen TD, Livak KJ (2008) Analyzing real-time PCR data by the comparative $C(T)$ method. Nat Protoc 3, 1101-8 
Solinas-Toldo S, Fries R, Steffen S, Neiberg HL, Barendse W, Wolmack JE, Hetzel DJ, Stranzinger G (1993) Physically mapped cosmid-derived microsatellite markers as anchor loci on bovine chromosomes. Mamm Genome 4, 720-7

Tiso N, Rampoldi L, Pallavicin A, Zimbello R, Pandolfo D, Valle G, Lanfranchi G, Danieli GA (1997) Fine mapping of five human skeletal muscle genes alpha-tropomyosin beta-tropomyosin troponin-I slow-twitch troponin-I fast-twitch and troponin-C fast. Biochem Biophys Res Commun 230, 347-50

Tontis A, Zwahlen R, Lobsiger C, Luginbühl H (1990) Pathology of bovine cardiomyopathy. Schweiz Arch Tierheilk 132, 105-6

Vallins WJ, Brand NJ, Dabhade N, Butler-Browne G, Yacoub MH, Barton PJ (1990) Molecular cloning of human cardiac troponin I using polymerase chain reaction. FEBS Lett 270, 57-61

Received 5 September 2008, accepted 16 December 2008.

Corresponding author:

MARTA OWCZAREK-LIPSKA

email: marta.owczarek@itz.unibe.ch

Institute of Genetics, Vetsuiss Faculty, University of Berne, Bremgartenstrasse 109a, 3001 Berne, Switzerland 